\title{
Impact of Game-Based Learning on Learning Motivation High School Students
}

\author{
Rizka Apriani \\ Department of Guidance and Counseling \\ Universitas Negeri Malang, Indonesia \\ rizka.apriani.fip@um.ac.id
}

\author{
Arif Prastiawan \\ Faculty of Education \\ Universitas Negeri Malang, Indonesia \\ arif.prastiawan@um.ac.id
}

\begin{abstract}
The goal of this research to determine differences in learning motivation between classroom using Game-Based Learning with classrooms using the conventional method at high school students. Quasi-experiment used in this research design with a pre-test post-test control group. The samples divide into an experimental group, which uses Game-Based Learning and control group using conventional methods. Using learning design instruments and test questions. Based on field data, the mean value of the pre-test experimental group 51.87and the control group 51.57. Once treated, the average value of the experimental group 83.80 and the control group 74.33. The results of the significance of the t-test $0.000<0.05$.
\end{abstract}

Keywords: impact, game-based learning, learning motivation

\section{INTRODUCTION}

Teachers an essential role in the improvement of human resources. One of the aims of education is so that people can develop their potential. This is in line with Republic Act No. national education system 20 of 2003 which states education is an effort to make the learners can actively develop her potential as self-control, religious, intelligence, personality, and skills needed in the community, the nation, and the State (Indonesia, 2003), Based on the educational goals, then the conclusion obtained is the purpose of the implementation of education creates human resources which classified and competitive. To achieve these objectives, we need innovation in learning effective and engaging in order to motivate learners to learn.

Results of interviews with some learners puffed up, get the facts about the many teachers who are dominant in using the lecture method. The method used by teachers lecture less according to the characteristics of learners in the 21st century (Kim \& Bateman, 2007; Longworth, 2003; Praherdhiono, Adi, \& Prihatmoko, 2018), Entering the 21st century, a very different learner characteristics (Bell, 2010), traditional learning approach to make learners passively consume content (Jovanovic, Chiong, \& Weise, 2012). Therefore, there must be a change, or at least complements the learning process more interactive and creative". Based on the above statement can be said that teachers should be able to adjust the characteristics of 21st-century learners to make innovations in the learning process.

One form of such innovation is the Game-Based Learning (GBL). Game-Based Learning strategy is presented to learners when they are involved in play the game. The underlying of this strategy is to increase learner learning motivation (Chen \& Law, 2016; Jong, Lai, Hsia, Lin, \& Lu, 2012). The game isn't the primary focus in the learning process, but the game only part of the strategy in the learning process. For example, integrating educational games with cooperative learning. When learners are shown many display with full-color design combine with sound effects and learning resources, learners are motivated to learn, and they learn better
(Chen \& Law, 2016; Ebner \& Holzinger, 2007; Jong et al., 2012), the researchers have applied Game-Based Learning in various levels of education and learning materials at Game-Based Learning using as an attempt to create a pleasant atmosphere and increase the learning motivation of learners to learn. Media is a tool or nonpersonal form of communication that functions as a lesson information to be presented to the learners (Allen, Otto, \& Hoffman, 1996; Mayer \& Mayer, 2005; Setyosari, 2005), Learning media as a bridge to attract the interest and attention of learners to achieve the learning objectives are well (Allen et al., 1996; Arends \& Castle, 1991), An assortment of media that can be used by teachers, both media made by the teachers themselves and the media provided by the campaigners education. Explain some characteristics of learning using Game-Based Learning as follows: (1) By participating in the game, motivation of learners to revisit the knowledge they had just gained; (2) easy to understand feedback from Game-Based Learning environment allows teachers to check the progress of each learner and provide appropriate advice at the right time; (3) Through the game, learners can exchange knowledge with each other; (4) The game allows learners to learn informally, so they do not feel tired; (5) At the time of playing games often accompanied by discussions and social activities (Nelson, 2007).

Generation of learners is currently growing by information and communication technologies (ICTs) are embedded in their daily lives. Present learners receive digital information every day, relationships with each other through mobile technology, interactive work, often do some tasks more or less simultaneously and play the game to a greater extent than previous generations (Beck \& Wade, 2006; Bell, 2010; Chen \& Law, 2016; Hampton $\&$ Keys, 2017), Night game along with ongoing research on the ability of Game-Based Learning in increasing learning motivation learners (Van Eck, 2006). It is thus very possible that Game-Based Learning may be inadequate to cope with the way children learn today. Direct involvement will add a success ratio in meaningful learning than traditional learning methods (Chen \& Law, 2016; Ebner \& Holzinger, 2007). 
Researchers of Game-Based Learning found in the learning games motivate learners to learn (Hwang, Chiu, \& Chen, 2015; Jong et al., 2012; Van Eck, 2006), Empirical evidence suggests that the motivating game. As an example, find that the game leads to a better attitude towards mathematics for grades 4 and 5 learners (Hwang et al., 2015). There are different game features, such as the structure of the game, the involvement of the game, and the attractiveness of the game, leading to a stronger learning motivation (Huang, Jeng, \& Huang, 2009). In a systematic comment of Game-Based Learning, the results of research that learners find a game that motivates (Connolly, Stansfield, \& Hainey, 2007). However, not all researchers agree that the game Game-Based Learning leads to stronger motivation.

For example, learners found that in an environment Game-Based Learning have higher intrinsic learning motivation but lower than the extrinsic learning motivation of learners in a conventional learning environment (Huang et al., 2009). Investigated the influence of games strategy on interest, competence and effort of learners and found that the learning motivation of learners who play games declined, but the learning motivation of learners who made the game increases (Van Eck, 2006). The results confirm about the relationship between game-based learning design and learning motivation are not always good. Possible depends on learning processes involving learners.

The learning process that does not involve or too hard will make the learners are not motivated. GameBased Learning to grow enjoyment and engagement of learners. Adding an external scaffold to the environment of Game-Based Learning (Barzilai \& Blau, 2014). They looking for an external scaffold had a significant negative impact on the learning motivation of learners. However, learners in certain circumstances have a better performance than those without scaffolding. The result is in favor of the idea of learning in the Game-Based Learning. Motivation is multidimensional construction (Csikszentmihalyi, 1990; Elliot \& McGregor, 2001; Ryan $\&$ Deci, 2000). The need for increasing satisfaction, which aims to better results.

Empirical evidence suggests that intrinsic learning motivation in Game-Based Learning environment direct to better learning outcomes for learners, for example as learning in the subjects of business, history, economics, and geography (Barzilai \& Blau, 2014; Huang et al., 2009), Granting autonomy broadly refers to learners to regulate behavior, their own experiences, initiation, and direction of learning (Ryan \& Deci, 2000), The game provides meaningful choices in learning for Player (Salen \& Zimmerman, 2005), It is towards the autonomy of learning on learners. Through the decision of the player, they are learning. In addition to autonomy, learners also need to feel competent to be grow up in their learning experience.

In an environment of Game-Based Learning, learners should have the sense to complete the assignment of the learning process with Game-Based Learning. When the task is too difficult for learners' games, they may not be inclined to engage in learning activities (Csikszentmihalyi, 1990). Therefore, the scaffolding that supports the activities of the learning process can be useful for motivation in educational games. The objective of this study was to determine whether there is a difference between classroom learning motivation using Game-Based Learning with classroom learning with conventional methods.

\section{METHODS}

A quasi-experimental design is a method used. Researchers chose a quasi-experimental design because the sample no takes at random, but predetermined. This study has one independent variable and one dependent variable. The independent variable /independent is the use of Game-Based Learning in learning strategies, while the dependent variable or dependent variable is the learning motivation of learners from high school. The study design is dividing the study group into two groups, and the experimental group will be using with the use of GameBased Learning, and control groups were studied using conventional methods. The study design can describe in Table 1.

Table 1

Codification Value of Principles

\begin{tabular}{|c|c|c|c|}
\hline Group & Pre-test & Treatment & Post-test \\
\hline Experiment & $\mathrm{O} 1$ & $\mathrm{X} 1$ & $\mathrm{O} 2$ \\
\hline Control & $\mathrm{O} 3$ & & $\mathrm{O} 4$ \\
\hline
\end{tabular}

\section{Information:}

O1: Pre-test (experimental group)

X1: Use GAME-BASED LEARNING

O2: Post-test (experimental group)

O3: Pre-test (control group)

O4: Post-test (control group)

There are two instruments used by researchers, learning design and test questions. In this study, two different study designs used in two different classes, the experimental class, and the control class. As for the test, there are two problems, namely the pre-test to ensure that both classes are at equal ability and post-test to measure the ability of the end of the learners. The second question in the form of an objective test (multiple choice).

To measure the validity of $t$ instrument validity test. Test validity testing in class XII who has obtained the material used, the chapter of the Japanese occupation. Item matter can be considered valid if $r_{\text {count }}>r_{\text {table }}$. Based on $\mathrm{N}=30$, then obtained $r$ table at 0.3610 . Validity significance level presented in Table 2.

Table 2

The Level of Significance Validity

\begin{tabular}{|c|c|}
\hline $\mathbf{d f}=(\mathbf{N}-2)$ & Significant Taraf $(\mathbf{0 . 0 5})$ \\
\hline 26 & .3739 \\
\hline 27 & .3673 \\
\hline $\mathbf{2 8}$ & $\mathbf{. 3 6 1 0}$ \\
\hline 29 & .3550 \\
\hline 30 & .3494 \\
\hline
\end{tabular}

The results of the data analysis have been carried out are presented in Table 3. 
Table 3

Problem Test Validity Test Results

\begin{tabular}{|c|c|c|c|}
\hline Grain Problem & r count & r table & Information \\
\hline Question 1 & 0,407 & .3610 & valid \\
\hline Question 2 & .528 & .3610 & valid \\
\hline Question 3 & .473 & .3610 & valid \\
\hline Question 4 & 0,482 & .3610 & valid \\
\hline Question 5 & 0,700 & .3610 & valid \\
\hline Question 6 & .677 & .3610 & valid \\
\hline Question 7 & 0.755 & .3610 & valid \\
\hline Question 8 & 0.647 & .3610 & valid \\
\hline Question 9 & 0.511 & .3610 & valid \\
\hline Question 10 & 0.739 & .3610 & valid \\
\hline Question 11 & 0.659 & .3610 & valid \\
\hline Question 12 & 0.586 & .3610 & valid \\
\hline Question 13 & 0.461 & .3610 & valid \\
\hline Question 14 & .453 & .3610 & valid \\
\hline Question 15 & 0.626 & .3610 & valid \\
\hline Question 16 & 0.755 & .3610 & valid \\
\hline Question 17 & 0.492 & .3610 & valid \\
\hline Question 18 & .528 & .3610 & valid \\
\hline Question 19 & .451 & .3610 & valid \\
\hline Question 20 & .664 & .3610 & valid \\
\hline Question 21 & .473 & .3610 & valid \\
\hline Question 22 & 0.454 & .3610 & valid \\
\hline Question 23 & 0.411 & .3610 & valid \\
\hline Question 24 & 0,482 & .3610 & valid \\
\hline Question 25 & .473 & .3610 & valid \\
\hline Question 26 & 0.372 & .3610 & valid \\
\hline Question 27 & .787 & .3610 & valid \\
\hline Question 28 & 0.411 & .3610 & valid \\
\hline Question 29 & .713 & .3610 & valid \\
\hline Question 30 & 0.586 & .3610 & valid \\
\hline
\end{tabular}

To measure the reliability coefficient of the test instrument carried out the reliability test. Reliability coefficient index criteria presented in Table 4. Reliability test results of test items present in Table 5.

Table 4

Criteria For The Reliability Coefficient Index

\begin{tabular}{|c|c|}
\hline Interval reliability index & Interpretation \\
\hline$<0.200$ & Very low \\
\hline 0.200 to 0.399 & Low \\
\hline 0.400 to 0.599 & Enough \\
\hline 0.600 to 0.799 & High \\
\hline 0.800 to 1.000 & Very high \\
\hline
\end{tabular}

Table 5

Results of Reliability Test

\begin{tabular}{|l|c|c|c|}
\hline & $\begin{array}{c}\text { Cronbach's } \\
\text { Alpha } \text { (R count) }\end{array}$ & $\begin{array}{c}\mathbf{r} \\
\text { table }\end{array}$ & Information \\
\hline Question Post-test & 0.909 & .3610 & realibel \\
\hline
\end{tabular}

From the above data, and following the criteria of reliability coefficient index, it can describe that the items using as a matter of its instrument of accession has very high reliability. Level of difficulty of the instrument tested with the level of difficulty. This test to find a matter category level easy, medium or difficult, it can be classified in Table 6. Results of analysis field data presented in Table 7. To distinguish between the learners in the upper class and the lower class do different power test items. The results of the analysis of the data presented in Table 8.

Table 6

Classification of Difficulty Index

\begin{tabular}{|c|c|}
\hline The difficulty index & Information \\
\hline 0.00 to 0.30 & Difficult Problem \\
\hline 0.31 to 0.70 & Problem Medium \\
\hline 0.71 to 1.00 & Problem Easily \\
\hline
\end{tabular}

Table 7

Test Results in The Level of Difficulty

\begin{tabular}{|c|c|c|c|c|}
\hline $\begin{array}{c}\text { No. } \\
\text { Question }\end{array}$ & B & JS & $\mathbf{P}$ & Information \\
\hline 1. & 25 & 30 & 0.83 & Easy \\
\hline 2. & 21 & 30 & 0.70 & moderate \\
\hline 3. & 26 & 30 & 0.87 & Easy \\
\hline 4. & 14 & 30 & 0.47 & moderate \\
\hline 5. & 14 & 30 & 0.47 & moderate \\
\hline 6. & 23 & 30 & 0.77 & Easy \\
\hline 7. & 24 & 30 & 0.80 & Easy \\
\hline 8. & 25 & 30 & 0.83 & Easy \\
\hline 9. & 26 & 30 & 0.87 & Easy \\
\hline 10. & 24 & 30 & 0.80 & Easy \\
\hline 11. & 24 & 30 & 0.80 & Easy \\
\hline 12. & 26 & 30 & 0.87 & Easy \\
\hline 13. & 27 & 30 & 0.90 & Easy \\
\hline 14. & 20 & 30 & 0.67 & moderate \\
\hline 15. & 21 & 30 & 0.70 & moderate \\
\hline 16. & 24 & 30 & 0.80 & Easy \\
\hline 17. & 26 & 30 & 0.87 & Easy \\
\hline 18. & 21 & 30 & 0.70 & moderate \\
\hline 19. & 24 & 30 & 0.80 & Easy \\
\hline 20. & 5 & 30 & 0.17 & Hard \\
\hline 21. & 26 & 30 & 0.87 & Easy \\
\hline 22. & 26 & 30 & 0.87 & Easy \\
\hline 23. & 29 & 30 & 0.97 & Easy \\
\hline 24. & 27 & 30 & 0.90 & Easy \\
\hline 25. & 26 & 30 & 0.87 & Easy \\
\hline 26. & 25 & 30 & 0.83 & Easy \\
\hline 27. & 24 & 30 & 0.80 & Easy \\
\hline 28. & 29 & 30 & 0.97 & Easy \\
\hline 29. & 22 & 30 & 0.73 & Easy \\
\hline 30. & 26 & 30 & 0.87 & Easy \\
\hline
\end{tabular}

Table 8

Analysis of Different Power Problem

\begin{tabular}{|c|c|c|c|c|c|c|}
\hline $\begin{array}{c}\text { No. } \\
\text { Question }\end{array}$ & $\mathbf{B}_{\mathrm{A}}$ & $\mathbf{B}_{\mathbf{B}}$ & $\begin{array}{c}\mathbf{P}_{\mathbf{A}}= \\
\mathbf{B}_{\mathbf{A}} / \mathbf{J}_{\mathbf{A}}\end{array}$ & $\begin{array}{c}\mathbf{P}_{\mathbf{B}}= \\
\mathbf{B}_{\mathbf{B}} / \mathbf{J}_{\mathbf{B}}\end{array}$ & D & Criteria \\
\hline 1. & 17 & 8 & 1 & 0.61 & 0.38 & moderate \\
\hline 2. & 16 & 5 & 0.94 & 0.38 & 0.55 & Well \\
\hline 3. & 17 & 9 & 1 & 0.69 & 0.30 & moderate \\
\hline 4. & 12 & 2 & 0.70 & 0.15 & 0.55 & Well \\
\hline 5. & 12 & 2 & 0.70 & 0.15 & 0.55 & Well \\
\hline 6. & 16 & 7 & 0.94 & 0.53 & 0.40 & moderate \\
\hline 7. & 17 & 7 & 1 & 0.53 & 0.46 & Well \\
\hline 8. & 16 & 9 & 0.94 & 0.69 & 0.24 & moderate \\
\hline 9. & 16 & 10 & 0.94 & 0.76 & 0.17 & Ugly \\
\hline 10. & 17 & 7 & 1 & 0.53 & 0.46 & Well \\
\hline 11. & 16 & 8 & 0.94 & 0.61 & 0.32 & moderate \\
\hline 12. & 17 & 9 & 1 & 0.69 & 0.30 & moderate \\
\hline 13. & 16 & 11 & 0.94 & 0.84 & 0.09 & Ugly \\
\hline 14. & 14 & 6 & 0.82 & 0.46 & 0.36 & moderate \\
\hline 15. & 16 & 5 & 0.94 & 0.38 & 0.55 & Well \\
\hline 16. & 17 & 7 & 1 & 0.53 & 0.46 & Well \\
\hline 17. & 17 & 9 & 1 & 0.69 & 0.30 & moderate \\
\hline 18. & 16 & 5 & 0.94 & 0.38 & 0.55 & Well \\
\hline 19. & 16 & 8 & 0.94 & 0.61 & 0.32 & moderate \\
\hline 20. & 5 & 0 & 0.29 & 0 & 0.29 & moderate \\
\hline 21. & 17 & 9 & 1 & 0.69 & 0.30 & moderate \\
\hline 22. & 17 & 9 & 1 & 0.69 & 0.30 & moderate \\
\hline 23. & 17 & 12 & 1 & 0.92 & 0.07 & Ugly \\
\hline 24. & 17 & 10 & 1 & 0.76 & 0.23 & moderate \\
\hline 25. & 17 & 9 & 1 & 0.69 & 0.30 & moderate \\
\hline 26. & 16 & 9 & 0.94 & 0.69 & 0.24 & moderate \\
\hline 27. & 17 & 7 & 1 & 0.53 & 0.46 & Well \\
\hline 28. & 17 & 12 & 1 & 0.92 & 0.07 & Ugly \\
\hline 29. & 17 & 5 & 1 & 0.38 & 0.61 & Well \\
\hline 30. & 17 & 9 & 1 & 0.69 & 0.30 & moderate \\
\hline
\end{tabular}




\section{RESULTS AND DISCUSSION}

Here is the result of the analysis of the pre-test value in the research presented in Table 9.

Table 9

Data Description Pre-test Results

\begin{tabular}{|c|c|c|c|}
\hline \multirow{3}{*}{$\begin{array}{c}\text { Pre- } \\
\text { test }\end{array}$} & Data & $\begin{array}{c}\text { Group } \\
\text { Experiment }\end{array}$ & $\begin{array}{c}\text { Group } \\
\text { Control }\end{array}$ \\
\cline { 2 - 4 } & $\mathrm{N}$ & 30 & 30 \\
\cline { 2 - 4 } & lowest Rated & 30 & 30 \\
\cline { 2 - 4 } & The highest score & 67 & 77 \\
\cline { 2 - 4 } & mean & 51.57 & 51.87 \\
\cline { 2 - 4 } & $\begin{array}{c}\text { standard } \\
\text { Deviation }\end{array}$ & 9.779 & 9.641 \\
\cline { 2 - 4 } & variance & 95.633 & 92.947 \\
\hline
\end{tabular}

From the table 9, the average value obtained pretest of 51.57 experimental group and the control group 51.87 so that the two groups together are in the same capacity. In the experimental group, the pre-test obtained the lowest score was 30, and the highest pre-test score is 67. While the lowest pre-test scores obtained by the control group were 30, and the highest pre-test score is 77. In Table 10 presented the results of the data analysis of the post-test values presented in Table 10.

Table 10

Data Description Post-Test results

\begin{tabular}{|c|c|c|c|}
\hline \multirow{3}{*}{$\begin{array}{c}\text { Post- } \\
\text { test }\end{array}$} & Data & $\begin{array}{c}\text { Experiment } \\
\text { group }\end{array}$ & $\begin{array}{c}\text { Control } \\
\text { group }\end{array}$ \\
\cline { 2 - 4 } & $\mathrm{N}$ & 30 & 30 \\
\cline { 2 - 4 } & lowest Rated & 70 & 60 \\
\cline { 2 - 4 } & The highest score & 97 & 87 \\
\cline { 2 - 4 } & mean & 83.80 & 74.33 \\
\cline { 2 - 4 } & $\begin{array}{c}\text { standard } \\
\text { Deviation }\end{array}$ & 7.063 & 6.687 \\
\cline { 2 - 4 } & variance & 49.890 & 44.713 \\
\hline
\end{tabular}

From the above table, the data obtained by the average value of the post-test experimental group 83.80 and the control group 74.33. So, it can be said that the average value of the experimental group was higher than the average value of the control group as a whole. In the experimental group obtained the lowest post-test score was 70 , and the highest post-test score is 97 . While the post-test scores lowest in the control group were 60 and the lowest post-test scores, the highest is 87 . To examine differences in learning outcomes of both classes, then tested the hypothesis that the t-test. Hypothesis testing formula is as follows: H0: There is no significant difference in learning motivation between classes using GAME-BASED LEARNING with classes using conventional methods. H1: There is a significant difference between the learning motivation class that uses GAME-BASED LEARNING class using the conventional method. The results of the t-test study results presented in Table 11 .

Table 11

Test-T Value Post-test

\begin{tabular}{|l|c|c|c|c|}
\multicolumn{6}{|c|}{ Test-T Value Post-test } \\
\hline \multirow{2}{*}{$\begin{array}{l}\text { Learning } \\
\text { outcomes }\end{array}$} & $\begin{array}{c}\text { Group } \\
\text { ment }\end{array}$ & T table & t & Sig. (2-tailed) \\
\cline { 2 - 5 } & 2.048 & 5.259 & 0,000 \\
\hline
\end{tabular}

Table 11 shows the number meaning significance of 0.000 , which is smaller than $0.05(0.000<0.05)$ or number $t$ is more significant than t table $(5.259>2.048)$
$\mathrm{H} 0$ is rejected so that the results of t-test showed that there were significant differences in learning outcomes between classes using GAME-BASED LEARNING with classes using conventional methods on learners senior high school. The results of research data that has been done about the effect of the use of Game-Based Learning media on the learning outcomes of students in high school that have increased rapidly. The findings of this study are supported by the findings of previous studies that have been conducted. One study mentioned that there was a significant positive increase in several subfactors of attitudes and students' self-efficacy scores in the experimental group compared to the average scores of students in the control group (Yukselturk, Altiok, \& Başer, 2018). Other studies have shown positive effects, but the results of this activity are still lacking (Huizenga, Admiraal, ten Dam, \& Voogt, 2019). In addition, further analysis shows that Game Based Learning can be useful for the mastery of the player's language, affective / psychological states, contemporary competencies, and participatory behavior (Acquah \& Katz, 2020). These studies indicate that the use of game-based learning can affect the final assessment of learning in students.

\section{CONCLUSION}

Based on the results of research data that has been done on the effect of the use of learning media GAMEBASED LEARNING to the learning outcomes of learners in senior high school, lead to the conclusion that the learning outcomes experimental group using instructional GAME-BASED LEARNING has increased rapidly. At the initial capability test, the average value of the experimental group is 51.57. Once treated and tests the average value rose to 83.80 . Based on the pre-test, the results of the learners learn the control group had an average score of 51.87. After the learning process and tests, the average value of the control group increased to 74.33. On the results of hypothesis testing using independent sample t-test obtained $t$ value of 5.259 and $t$ table amounted to 2.048 and 0.000 significance value. Therefore, the value of $\mathrm{t}>\mathrm{t}$ table and the significance value $<0.05$, then there are significant differences in learning outcomes between classes using GAME-BASED LEARNING with classes using the conventional method in senior high school students.

\section{REFERENCES}

[1] Acquah, E. O., \& Katz, H. T. (2020). Digital game-based L2 learning outcomes for primary through high-school students: A systematic literature review. Computers \& Education, 143, 103667. https://doi.org/https://doi.org/10.1016/j.compedu.2019.103 667

[2] Allen, B. S., Otto, R. G., \& Hoffman, B. (1996). Media as lived environments: The ecological psychology of educational technology. Handbook of Research for Educational Communications and Technology: A Project of the Association for Educational Communications and Technology, 199-225.

[3] Arends, R., \& Castle, S. (1991). Learning to teach (Vol. 2). McGraw-Hill New York.

[4] Barzilai, S., \& Blau, I. (2014). Scaffolding game-based learning: Impact on learning achievements, perceived 
learning, and game experiences. Computers \& Education, 70, 65-79.

[5] Beck, J. C., \& Wade, M. (2006). The kids are alright: How the gamer generation is changing the workplace. Harvard Business Press.

[6] Bell, S. (2010). Project-based learning for the 21st century: Skills for the future. The Clearing House, 83(2), 39-43.

[7] Chen, C.-H., \& Law, V. (2016). Scaffolding individual and collaborative game-based learning in learning performance and intrinsic motivation. Computers in Human Behavior, $55,1201-1212$.

[8] Connolly, T. M., Stansfield, M., \& Hainey, T. (2007). An application of games-based learning within software engineering. British Journal of Educational Technology, 38(3), 416-428.

[9] Csikszentmihalyi, M. (1990). The domain of creativity.

[10] Ebner, M., \& Holzinger, A. (2007). Successful implementation of user-centered game based learning in higher education: An example from civil engineering. Computers \& Education, 49(3), 873-890.

[11] Elliot, A. J., \& McGregor, H. A. (2001). A $2 \times 2$ achievement goal framework. Journal of Personality and Social Psychology, 80(3), 501

[12] Hampton, D. C., \& Keys, Y. (2017). Generation Z students: Will they change our nursing classrooms. Journal of Nursing Education and Practice, 7(4), 111-115.

[13] Huang, Y.-M., Jeng, Y.-L., \& Huang, T.-C. (2009). An educational mobile blogging system for supporting collaborative learning. Journal of Educational Technology \& Society, 12(2).

[14] Huizenga, J., Admiraal, W., ten Dam, G., \& Voogt, J. (2019). Mobile game-based learning in secondary education: Students' immersion, game activities, team performance and learning outcomes. Computers in Human Behavior, 99, 137-143

[15] Hwang, G.-J., Chiu, L.-Y., \& Chen, C.-H. (2015). A contextual game-based learning approach to improving students' inquiry-based learning performance in social studies courses. Computers \& Education, 81, 13-25.

[16] Indonesia, R. (2003). Undang-undang Republik Indonesia nomor 20 tahun 2003 tentang sistem pendidikan nasional. Jakarta: Pemerintah Republik Indonesia.

[17] Jong, B.-S., Lai, C.-H., Hsia, Y.-T., Lin, T.-W., \& Lu, C.Y. (2012). Using game-based cooperative learning to improve learning motivation: A study of online game use in an operating systems course. IEEE Transactions on Education, 56(2), 183-190.

[18] Jovanovic, J., Chiong, R., \& Weise, T. (2012). Social networking, teaching, and learning. Interdisciplinary Journal of Information, Knowledge, and Management, 7, $38-43$.

[19] Kim, H. K., \& Bateman, B. (2007). Student characteristics and participation patterns in online discussion. Society for Information Technology \& Teacher Education International Conference, 2381-2387. Association for the Advancement of Computing in Education (AACE).

[20] Longworth, N. (2003). Lifelong learning in action: Transforming education in the 21 st century. Routledge.

[21] Mayer, R., \& Mayer, R. E. (2005). The Cambridge handbook of multimedia learning. Cambridge university press.

[22] Nelson, B. C. (2007). Exploring the use of individualized, reflective guidance in an educational multi-user virtual environment. Journal of Science Education and Technology, 16(1), 83-97.

[23] Praherdhiono, H., Adi, E. P., \& Prihatmoko, Y. (2018). KONSTRUKSI DEMOKRASI BELAJAR BERBASIS KEHIDUPAN PADA IMPLEMENTASI LMS DAN MOOC. Edcomtech Jurnal Kajian Teknologi Pendidikan, $3(1), 21-28$.

[24] Ryan, R. M., \& Deci, E. L. (2000). Self-determination theory and the facilitation of intrinsic motivation, social development, and well-being. American Psychologist, $55(1), 68$

[25] Salen, K., \& Zimmerman, E. (2005). Game design and meaningful play. Handbook of Computer Game Studies, 59,79 .

[26] Setyosari, P. (2005). Media Pembelajaran. Malang: Elang Mas.

[27] Van Eck, R. (2006). Digital game-based learning: It's not just the digital natives who are restless. EDUCAUSE Review, 41(2), 16.

[28] Yukselturk, E., Altık, S., \& Başer, Z. (2018). Using Game-Based Learning with Kinect Technology in Foreign Language Education Course. Journal of Educational Technology \& Society, 21(3), 159-173. 